\title{
THE CONSEQUENCES OF FOREIGN DIRECT INVESTMENTS IN REDEFINING BILATERAL TRADE FLOW IN NIGERIA: A GRAVITY PANEL APPROACH
}

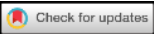

Saidu D.

Muhammad $^{1}$

Kenneth O.

Diyoke $^{2}$

(iD) Nnanna P. $\mathrm{Azu}^{3+}$

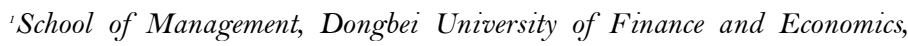
Dalian, China.

${ }^{2}$ Email:sdmuhammad@yahoo.com Tel: +2348022062397

'Email:dkofirst@yahoo.com Tel: +2348035044574

${ }^{2, s}$ Department of Economics, Nile University of Nigeria, Abuja Nigeria.

${ }^{s}$ Email:nnanna.azu@nileuniversity.edu.ngTel:+2348132547486

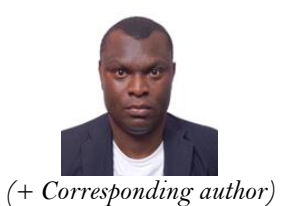

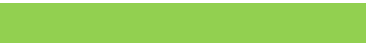

Article History

Received: 6 December 2019 Revised: 24 January 2020 Accepted: 3 March 2020

Published: 26 March 2020

Keywords

Trade

Gravity

Foreign direct investment

Nigeria

PPML

Regional trade agreement.

JEL Classification: F14, F21, F15.

\begin{abstract}
Most of the Nigerian government's transformation agenda is geared toward creating and enabling business environments to attract foreign direct investment. Opinions are divided as to the impact of foreign investment on trade and this researcher believed it could be either positive or negative. Hence, this research is to ascertain the magnitude of foreign investment's impact on Nigeria's bilateral trade. Integrating foreign direct investment in the gravity model, we applied the PPML technique because of its robustness and ability to recognise zero trade. We segregated foreign investment into three-flow, stock and its annual growth. Our estimation revealed that foreign direct investment stock impacts negatively on bilateral trade flow in Nigeria for both exports and imports and it is robust with the overall sample. Exporters' foreign direct investment inflow was also revealed to have an impact on bilateral trade in Nigeria. But in all ramifications the magnitude of the negative impact is relatively small but statistically significant reflecting that trade and inward foreign investment are at least substitutes. Nigeria should further encourage inward foreign investment to further stimulate economic growth and aid in creating import substitution.
\end{abstract}

Contribution/ Originality: This study uses new estimation methodology and the model to determine the impact of foreign direct investment (FDI) on Nigeria's trade development. The impact of FDI was measured from three perspectives; stock, flow and growth. The paper revealed there is a robust and statistically significant negative effect of FDI on trade, though very negligible.

\section{INTRODUCTION}

Economic transformation has been a major target of every government regime in Nigeria which has led to various transformation programmes to encourage investments from both domestic and foreign investors. According Yusoff and Nuh (2015) most government transformation strategy starts by employing the exportoriented development strategy and giving more incentives to attract foreign direct investment (FDI) which is not different from Nigeria's initiatives.

Literature on international economics has widely discussed the significance of FDI in developing economies. Sahoo and Sethi (2017) noted that foreign capital in the form of FDI assists to prevail over the downsides that most developing economies encounter (inadequate capital), as it augments adequate physical and financial capital, product innovations, market information, technical know-how, advanced production techniques and foreign exchange 
resources, skilled personnel and new experiences in an organisation. This supports some research that states that there could be positive linkage between FDI and economic growth (Alfaro, Chanda, Kalemli-Ozcan, \& Sayek, 2010; Ghatak \& Halicioglu, 2007; Lensink \& Morrissey, 2006). The opposing argument states that FDI may lead to increase in balance of payment problems and could allow for the exploitation of the host country's market thus, shrinking the capability of such country to manage its economy (Jawaid, Raza, Mustafa, \& Karim, 2016) while some other studies have found no relationship between FDI and economic growth (Chakraborty \& Basu, 2002; Dhakal, Rahman, \& Upadhyaya, 2007).

The argument for the importance of FDI on economic growth has been persistent just as its impact on trade development is controversially diverse. The optimistic school believes that FDI does significantly improve the level of international trade. For instance, Aizenman and Noy (2006) found that there was strong feedback between FDI and trade from the manufacturing sector, similar to Le (2017)'s study on Vietnam's trade inflow of FDI. Similarly, Burange, Thakur, and Kelkar (2017) expressed that FDI inflows in India have led to an increase in intra-industrial trade for the manufacturing sector. Several other authors believe there are positive linkages between FDI inflow and trade (Egger, 2001; Fontagné \& Michaël, 1997; Jayachandran \& Seilan, 2010) which sometimes are causal (Zhang \& Felmingham, 2001). A peculiar argument presented by this group is that FDI affords the host country a competent, skilled and advanced method of production which enhances production quality and boost domestic output, and thus will aid penetration of the export market just as new products could be launched for exports. FDI also promotes the growth in human capital formation by facilitating training and knowledge sharing and advances transfer of technology.

Aforementioned production and quality enhancement activities could greatly motivate export performance of FDI host countries. Mohamed (2014) believes that inward FDI enhances the general productivity level of both the developing and emerging economies' exports. Therefore, the issue of inward FDI as a positive influence on trade generally depends partly on the quality of products. Hence, Rodrik (2006); Hausmann, Hwang, and Rodrik (2007); Wang and Wei (2010a); Wang and Wei (2010b) reasoned that it doesn't matter how much you trade but that what you export is paramount. The presence of foreign firms could be associated with high quality of exported goods from FDI host economies (Chen \& Swenson, 2014; Harding \& Javorcik, 2012; Wang \& Wei, 2010a; Wang \& Wei, 2010b). Therefore, the contribution of inward FDI toward trade development does not singularly depend on the number of FDI inflows but is highly dependent on the quality of products that the multinational firms are generating in the host countries.

The pessimistic school of thought may not rule out completely attracting inward FDI but is of the opinion that it does not in any way improve international trade. Using ARDL technique, Mohanty and Sethi (2019) found that there is a negative and significant impact of FDI on real exports in long term but positive in the short term. Theoretically, FDI would replace trade under the conditions of perfect competition. However, in the case of imperfectly competitive markets with economies of scale, technological changes and product differentiation, FDI and trade would complement each other (Agmon, 1979; Markusen. \& Venables, 1995; Markusen.. \& Maskus, 1999). There is the likelihood of inward FDI to influence trade negatively with horizontal FDI while vertical FDI could bring positive influence on trade (Helpman, 1984; Markusen, 1984; Markusen.. 1997).

In the Nigerian context, inward FDI is reasoned to have negative effect on economic growth (Adelegan, 2000) while others found no significant positive impact of FDI on economic growth (Akinlo, 2004; Ehigiamusoe \& Lean, 2019; Temiz, Gökmen, \& Abubakar, 2015). Temiz et al. (2015) adopted the Johansen Cointegration method while Ehigiamusoe and Lean (2019) utilised the Autoregressive Distributed Lagged (ARDL) model to arrive at a similar conclusion. However, Adeniyi, Omisakin, Olusegun, Egwaikhide, and Oyinlola (2012) are of the view that the effect of FDI on economic growth in developing countries is subject to the degree of financial sophistication of the host country. Even with the growing reports on the impact of FDI on economic growth in Nigeria, little has been said on the relationship between bilateral trade and FDI inflow in Nigeria, a gap which this research intends to fill. 
The scope and method of analyses could generally influence the outcome of most research on how FDI influences trade development. This paper examined the impact of FDI on bilateral trade development in Nigeria using a superior econometrics method. The paper adopted a standard gravity model approach and integrated FDI as a trade determining factor. We applied the Poisson Pseudo Maximum Likelihood (PPML) estimation technique. This technique is said to be robust and consistent, and also able to recognise zero trades (Silva \& Tenreyro, 2011). The outcome revealed a significant negative impact of FDI stock on bilateral trade development in Nigeria. A gravity model was applied by Aliyu and Bawa (2015) to assess Nigerian trade determinant but did not capture FDI and the method of analysis was restricted to ordinary least square (OLS) with fixed effect.

To achieve the general aim of this research, the remaining parts of the paper are organised as follows: section 2 highlights the connection between FDI and trade in Nigeria reflecting on various government efforts to attracts more foreign investment, the subsequent sections report the methodological note, analyses and discussion and the final section gives the concluding remarks.

\section{FOREIGN DIRECT INVESTMENT AND TRADE FLOW IN NIGERIA}

Researchers claim there are predictably enormous benefits accrued to recipient economies of inward FDI. Goldberg and Klein (1998) proclaimed that FDI inspires import substitution and export promotion leading to more trade in intermediate input which occasionally exist between parent and affiliated producer. Spill-over advantages of FDI could lead to reductions in unemployment rates as foreign firms seek to augment their labour force with the local labour supply. In light of this, the Nigerian government has been making efforts to sustain the inflow of investment from overseas especially after the failed nationalisation policy of 1979 .

The Nationalisation policy (which was also referred to as Indigenisation policy) according to Muhammad, Azu, and Oko (2018) aimed at protecting the Nigerian economy from the invasion of foreign investors to avoid economic and political dominance by foreign elites. This was achieved by converting major foreign owned investment into government control so that the government would take ownership of between $40 \%$ to $50 \%$ of the shares thereby restricting the percentage owned by foreign investors.

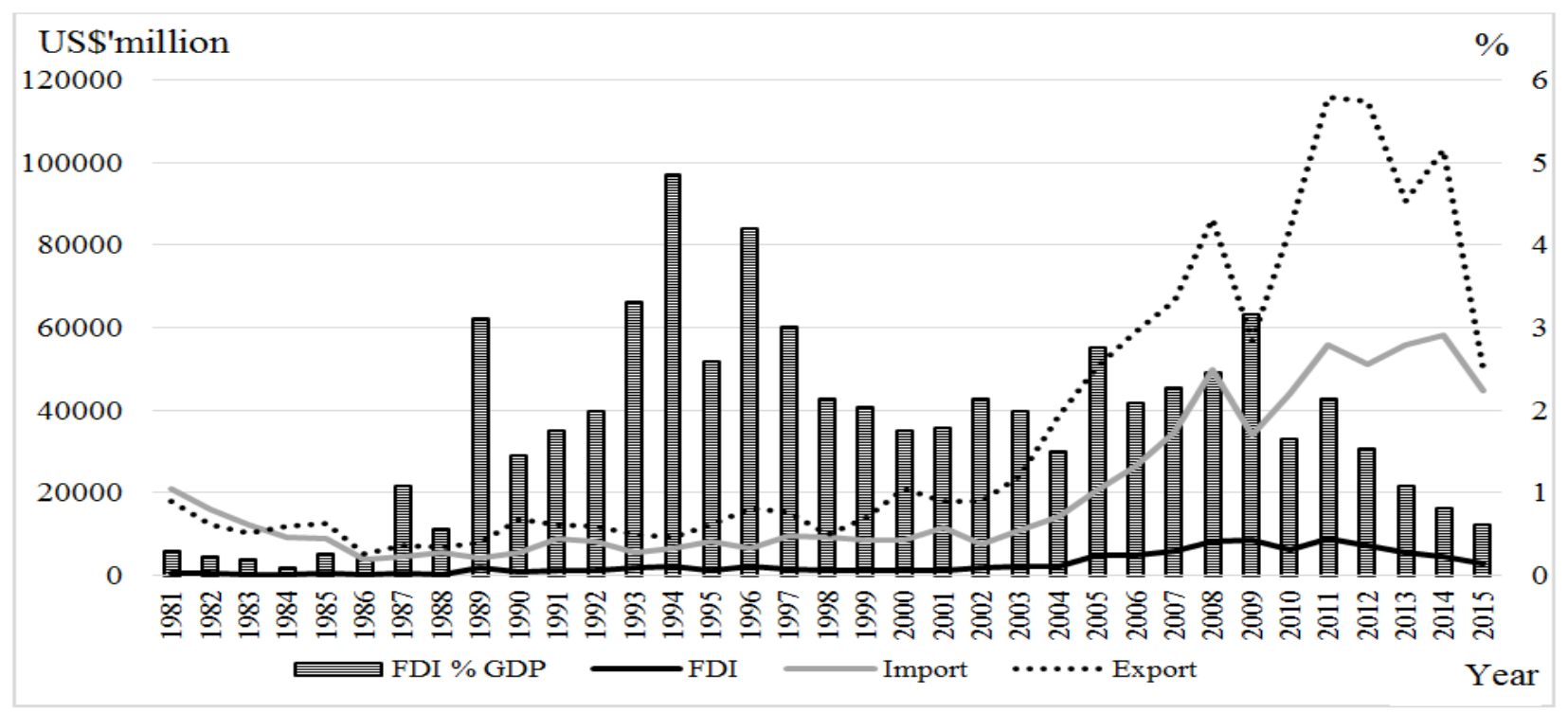

Source: UNCTAD

Figure-1. FDI inflow and trade in Nigeria.

This failed policy had resulted in negative FDI inflow in 1980 and slow inflow in the early 1980s. At this time, both exports and imports were also slowing down as imports reduced from US $\$ 20877$ million in 1981 to US\$8877 million in 1985. Likewise, exports had reduced from US\$17845 million in 1981 to US\$5155 in 1986 . The slow 
inflow of FDI and the reduction in trade may have demonstrated that FDI is responsible for trade generation during this period.

For the period under review, the average ratio of FDI to GDP never exceeded 1.8 per which could question its contribution to economic growth as well as trade development in Nigeria. As in Figure 1, the biggest ratio could be seen in 1994 when the ratio of FDI to GDP stood at a little over 4.8 per cent. In order to attract more foreign investment, the Nigerian government enacted the Nigerian Enterprises (repeal) Act which abolished the nationalisation policy and also established the Nigerian Investment Promotion Commission Act charged with facilitating and promoting investment in the country. The consequences included an increase in FDI inflow from US $\$ 1271.05$ in 1995 to US\$2190.68 in 1996 but the momentum was not sustained due to the inconsistency of the military regime. Even though exports rose from US $\$ 12342$ in 1995 to US\$16153.6 in 1996, imports were not improving at the same time as shown in Figure 1.

A return to civil rule in 1999 was followed by an improvement in perception and dealing with external sectors. Various polices were put in place to motivate investment in Nigeria and one was the introduction of National Economic Empowerment and Development Strategy (NEEDS) which aimed at gradually withdrawing government's direct involvement in commercial activities and paving way for a private sector-led economic growth strategy.

The policy was the forerunner for the later privatisation policy which opened the door for private investment in Nigeria and the increase in the amount of inward FDI in the country. Nigeria began to witness increased investment in telecommunication, power, transport and most importantly the oil sectors. Between the period of 2008 and 2014, Nigeria had become the highest destination for FDI in Africa with inflow of US\$8248.64 million in 2008, US\$8914.89 million in 2011 but declined to US\$5608.45 million in 2013 as can be seen in Figure 1 but was still regarded as the top FDI destination in Africa. The period is popularly termed the period of FDI boom in Nigeria. These periods were also characterised with trade liberalisation which ensured that Nigeria improved much in its traded sector of the economy as can be seen in Figure 1.

\section{METHODOLOGICAL NOTES}

\subsection{Augmenting the Gravity Model and Sources of Data}

The connotation of the original gravity equation signifies that bilateral trade varies directly to the product of both trading partners' income and inversely proportional to the distance between them. Though the model has been empirically successful, it was judged to lack the micro-theoretical foundation to fully explain its economic meaning. Hence, in a successful attempt to provide hitherto non-existent theoretical underpinning, Anderson. (1979); Anderson and Wincoop (2003); James and Wincoop (2004) proposed the gravity equation based on the constant elasticity of substitution (CES) function and differentiating goods based on the country or region of origin. Anderson and Wincoop (2003) initiated the structural gravity model by presenting the equation in a multiplicative form following the framework of general equilibrium. The demand for goods consumed in country $\mathrm{j}$, and imported from country i, is represented in Equation 1. Thus;

$$
\begin{aligned}
& M_{i j t}=\left\{\frac{\mathrm{Y}_{\mathrm{it}} \mathrm{Y}_{\mathrm{jt}}}{\mathrm{Y}_{\mathrm{t}}^{W}}\right\}\left\{\frac{\tau_{\mathrm{ijt}}}{\Pi_{\mathrm{i}} \mathrm{P}_{\mathrm{j}}}\right\}^{1-\sigma} \mu_{i j t} \\
& \pi_{i}=\Sigma_{\mathrm{j}}\left(\left(\frac{\tau_{\mathrm{ij} \mathrm{t}}}{\mathrm{P}_{\mathrm{j}}}\right)^{1-\sigma} \theta_{\mathrm{j}}\right)^{\frac{1}{(1-\sigma)}} \frac{\mathrm{Y}_{\mathrm{jt}}}{\mathrm{Y}_{\mathrm{t}}^{W}} \\
& P_{j}=\Sigma_{\mathrm{i}}\left(\left(\frac{\tau_{\mathrm{ij} \mathrm{t}}}{\Pi_{\mathrm{i}}}\right)^{1-\sigma} \theta_{\mathrm{i}}\right)^{\frac{1}{(1-\sigma)}} \frac{\mathrm{Y}_{\mathrm{it}}}{\mathrm{Y}_{\mathrm{t}}^{W}}
\end{aligned}
$$


Where $M_{i j t}$ stands for import from i to j, $\mathrm{Y}_{\mathrm{it}}$ and $\mathrm{Y}_{\mathrm{jt}}$ are respective incomes of country i and j, expressed as share of the world gross domestic product $Y_{t}^{W}, \tau_{\mathrm{ij}}$ would mean the ice-berg trade cost incurred as result of conveying the goods from country i to country $\mathrm{j}, \Pi_{\mathrm{i}}$ is the outward multilateral resistance; established by Equation 2 and $\mathrm{P}_{\mathrm{j}}$ stands for the inward multilateral resistance; established by Equation $3, \mu_{i j \mathrm{t}}$ represents some unexplained variables that affects trade and which would not be captured in the model. Note that in this research, products are known to be merchandise goods. Both the exporter (i) income and the importer (j) income are denote by $\theta_{\mathrm{i}}=\frac{Y_{\mathrm{it}}}{Y_{\mathrm{t}}^{W}}$ and $\theta_{\mathrm{j}}=\frac{Y_{j t}}{Y_{t}^{W}}$ respectively. Iceberg trade cost takes into consideration every factor that either enhances or retards international trade development. Anderson and Wincoop (2003) noted that during estimation, it is very crucial to accommodate both outward and inward multilateral resistance (MRT) in the regression. Therefore, to demonstrate the relationship between trade and incomes, trade costs and multilateral resistance to trade. Noting that trade, income and multilateral resistance all occur at a given time and express the equation in natural logarithm as represented by Equation 4. Viz;

$$
\ln M_{i j t}=Y_{i t}+Y_{j t}-Y_{t}^{W}+(1-\sigma)\left[\ln \left(\tau_{i j t}\right)+\ln \left(\pi_{i t}\right)-\ln \left(P_{j t}\right)\right]+\mu_{i j t}
$$

In augmenting the gravity, the variables of interest have been carefully selected to ensure that the aim and purpose of this research is attained. Most trade costs have been justified in previous studies to significantly determine international trade flows. But some major concerns state that some of the trade costs are not directly observable and as such, cannot be quantified. Meanwhile, in most cases, some variables can be represented by a proxy while others are captured as dummy variables. James and Wincoop (2004) suggested that all the costs except for marginal cost of production related with transferring goods to the final consumers are appropriately captured as trade costs. In production theory, production remains incomplete until the goods reaches final consumer, and those expenditures that directly or indirectly associated with conveying the goods from a point of production to point of consumption are combined to form the total trade costs. In other words, trade costs are too numerous to be captured in a single gravity equation and James and Wincoop (2004) stressed that $\tau$ could represent all variables in trade cost whether as recognised in their gravity equation or otherwise. This has allowed many researchers to substitute $\tau$ for any identifiable trade determinants.

Therefore, in this paper, trade costs were determined to consist of three components; the geographical variables $(\mathrm{G})$, Foreign Direct Investment $(\mathrm{F})$, and other Trade costs $(\mathrm{R})$. Trade cost estimated in average bilateral trade barriers function was represented by Equation 5;

$$
\tau_{i j t}=\text { dist }_{i j} e^{\beta_{1} G_{i j}+\beta_{2} F_{i j t}+\beta_{g} R_{i j t}+\mu_{i j t}}
$$

Where dist $_{i j}$ represents distance between pair of trading partners, $G_{i j}$ was a vector that included; contiguity, common language and common colonisation history. These variables are standard gravity variables which are necessary for estimation of the models. $F_{i j t}$ stands for a vector that includes both the exporter and importer 
foreign direct investment. FDI is believed to have positive influence on economic development and is reported to also encourage trade development which largely depends on the kind of FDI and purpose.

This research aimed to estimate the impact of FDI on bilateral trade with Nigeria. In this research foreign direct investment will be represented in three forms: inward FDI flow, FDI stock and FDI growth. This enabled us to obtain a robust result. FDI flow represented the net annual inflow while FDI stock was the annual total stock of FDI in Nigeria which is usually cumulative. The FDI growth stood for the annual change in FDI (increase/decrease) measured in percentage.

Table-1. Expected sign of coefficient results and sources of data.

\begin{tabular}{|c|c|c|}
\hline Variable Name & Expected Signs & Sources \\
\hline $\mathrm{M}_{\mathrm{ijt}}$ & Dependent & IMF, Direction of Trade Statistics \\
\hline$Y_{\text {it }}$ & Positive $(+)$ & \multirow{2}{*}{ UNCTAD } \\
\hline $\mathrm{Y}_{\mathrm{jt}}$ & Positive $(+)$ & \\
\hline Dist $_{i j}$ & Negative $(-)$ & \\
\hline Contig $_{i j}$ & Positive $(+)$ & CEPII \\
\hline Comlang_off $f_{i j}$ & Positive (+) & \\
\hline $\mathrm{Comcol}_{\mathrm{ij}}$ & Positive $(+)$ & \\
\hline $\mathrm{FDI}_{\mathrm{it}}$ & Positive $(+)$ & UNCTAD \\
\hline $\mathrm{FDI}_{\mathrm{jt}}$ & Positive $(+)$ & UNCTAD \\
\hline $\mathrm{RTA}_{\mathrm{ijt}}$ & Positive $(+)$ & WTO \\
\hline
\end{tabular}

$R_{i j t}$ was a vector that contained control variables which in this case was Regional Trade Agreement (RTA). Nigeria is a member of the Economic Community of West African States (ECOWAS) which is an RTA. Lastly, $\mu_{i j z}$ was the error term assumed to be normally distributed. Since the influence of FDI on trade could be indirect towards trade, and hence not be linear, adopting an exponential form became necessary. Equation 5 can be translated into a simple linear form and expanded to accommodate the needed variables as will be used in the analyses. Thus, Equation 6 emanated as follows;

$$
\begin{aligned}
& \ln M_{i j t}=\alpha+\gamma_{t}+\lambda_{j}+\phi_{i}+\beta_{1} \ln Y_{i t}+\beta_{2} \ln Y_{j t}+\beta_{3} \operatorname{lnDist}_{i j}+\beta_{4} \text { Contig }_{i j}+\beta_{5} \text { Comlang- } \\
& \text { off }_{i j}+\beta_{6} \text { Comcol }_{i j}+\beta_{7} F D I_{i t}+\beta_{8} F D I_{j t}+\beta_{9} \text { RTA }_{i j t}++\mu_{i j t}+\mathrm{\eta}_{i j t}
\end{aligned}
$$

Where:

$\mathrm{M}_{\mathrm{ijt}}$

$\mathrm{Y}_{\text {it }}$

$\mathrm{Y}_{\mathrm{jt}}$

Dist $_{\mathrm{ij}}$

Contigij

Comlang_off $\mathrm{ij}_{\mathrm{ij}}$

Comcol $_{\mathrm{ij}}$

$\mathrm{FDI}_{\text {it }}$

$\mathrm{FDI}_{j \mathrm{t}}$

RTA $_{i j t}$
Stands for the nominal value of import from country (i) to country (j).

Represents nominal GDP of the exporting country (i).

Represents the importing countries' (j) nominal GDP.

Stands for distance between importing country (j) and exporting country (i).

Is a dummy variable which takes the value of 1 if country $i$ and $j$ shares a common border and 0 otherwise.

Is a dummy which takes the value of 1 if both importing and exporting countries speak the same official language and o otherwise.

Is a dummy which takes the value of 1 if both exporting and importing countries were colonised by the same country and o otherwise.

Represents exporting country foreign direct investment.

Represents importing country foreign direct investment.

Stand for regional trade agreement. 
$\mu_{\mathrm{ijt}}$

$\eta_{\mathrm{ijt}}$

Constant variable.

Year Fixed Effects.

Importer Fixed Effects.

Exporter Fixed Effects.

error term of the general equation.

error term of the selected equations.

To complete the gravity model, exporter and importer fixed effects are included to capture the outward MRT, $\phi_{\mathrm{i}}$ and inward MRT $\chi_{\mathrm{j}}$. Time fixed effects are captured by $\gamma_{\mathrm{t}}$. The variables sources and expected coefficient signs are summarised in Table 1. Data range is from 1981 to 2015 with eighty (80) countries including Nigeria and its most important trading partners. It should be noted that trade as represented here is imports.

\subsection{Estimation Technique}

In international economies more especially trade, the choice of the best suitable estimation technique for the gravity model has become topical and sometimes controversial. Many estimation techniques have evolved yet argument abounds. Most scholars have been very critical of employing the pooled OLS on fundamental grounds; it fails to recognise zero trade. The Feasible Generalised Least Square (FGLS), truncated OLS and OLS Censored techniques are unable to handle heteroskedasticity and lack consistency (Martin \& Pham, 2008; Xiong \& Chen, 2012).

Most researchers are in favour of the two-steps Heckman technique as well as the Poisson Pseudo Maximum Likelihood (PPML) technique. Both methods are preferred in this field of study but Heckman (1979) and Helpman, Melitz, and Rubinstein (2008) have been proved to be too sensitive (Shepherd, 2013; Silva \& Tenreyro, 2011). Therefore, we used the PPML technique for its obvious advantages; the ability to recognise zero trades, consistency and robustness (Santos \& Tenreyro, 2006; Silva \& Tenreyro, 2011).

Following Azu (2019) we used importer, exporter and year fixed effect to capture various multilateral resistance and unobserved heterogeneity. The coefficient of the logarithm of the continuous variable was simply the elasticity of (the value of trade flows) with respect to the continuous variable (Disdier \& Head, 2008; Head \& Mayer,

$2014)$ while that of dummy variable was converted to inverse natural logarithm as $\left(\left(e^{\beta}-1\right) * 100\right)$ (Baier \&

Bergstrand, 2007).

The trade cost to be estimated in this regard is the average bilateral trade barriers function as represented by Equation 8;

$$
\tau_{i j t}=\left\{\beta_{3} \operatorname{lnDist}_{i j} e^{\left(\begin{array}{c}
\beta_{4} \text { Contigij }_{i j}+\beta_{5} \text { Comlang }_{0 f f}+\beta_{6} \text { Comcol }_{i j} \\
+\beta_{7} F D I_{i t}+\beta_{8} \text { FDI }_{j t}+\beta_{9} R T A_{i j t}+\mu_{i j t}
\end{array}\right)}\right\}
$$

To specifically capture Nigeria (sub-sample), which was the subject of interest in this research, Equation 8 was modified; thus, generating Equation 9 as follows;

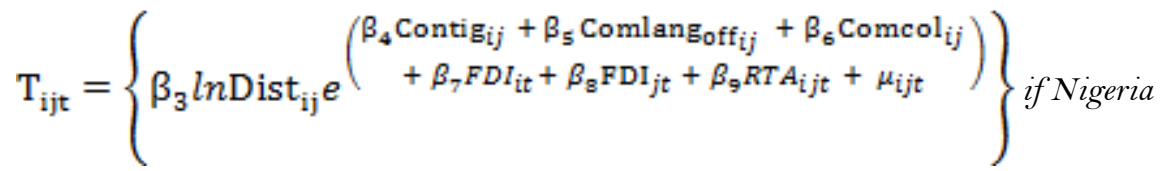

\section{RESULTS AND DISCUSSION}

The summary statistics are reported in Appendix 1 while correlation coefficients are displayed in Appendix 2. Correlation coefficients indicated that no variables were correlated which means there was no exact or linear dependence among the regressors which reduced multicollinearity issues. Table 2 shows the outcome of the regression analyses indicating the effect of FDI on bilateral trade in Nigeria while a similar result with respect to 
the full sample is reported in Appendix 3. The impact of FDI was captured in three ways; as a flow, stock and growth in FDI and its estimated results reported side by side.

\subsection{FDI and Trade}

There was an indication that FDI inflow influences bilateral trade negatively. Both results from the full and Nigerian samples were similar. Appendix 3 which reports the outcome of the full sample reveals that the flow of FDI into the exporting country may restrict trade with partners, which was statistically significant at one percent. Importers' FDI reported similar coefficients but was not statically significant in both Nigerian and full samples.

In the same vein, looking at the impact of FDI stock on trade development, it shows that both the importers' and exporters' FDI has a negative effect on bilateral trade development. This was similar in both the Nigerian and full samples and was statistically significant at one per cent in each case.

In international economies there have been arguments on how FDI influences bilateral trade as different authors reported diverse results following their own methods of analysis. FDI could influence bilateral trade depending on its motives. A rent-seeking FDI will definitely result in negative influence on bilateral trade since its intention is to expand the market rather than create more products for export from the host country. The outcome here supports this claim. The result in Table 2 reflected a peculiar case in Nigeria which was no different from the outcome of the full sample.

Table-2. Analysis of the Effect of FDI on Trade in Nigeria.

\begin{tabular}{|c|c|c|c|}
\hline & $(1)$ & $(2)$ & $(3)$ \\
\hline Variables & Flow & Stock & Growth \\
\hline \multirow[t]{2}{*}{$\ln \mathrm{Y}_{\mathrm{it}}$} & $0.941 * * *$ & $0.820^{* * * *}$ & $0.938^{* * * *}$ \\
\hline & $(0.0758)$ & $(0.0775)$ & $(0.0752)$ \\
\hline \multirow[t]{2}{*}{$\ln \mathrm{Y}_{\mathrm{jt}}$} & 1.037 **** & $0.880^{* * * *}$ & $1.027 * * *$ \\
\hline & $(0.106)$ & $(0.0882)$ & $(0.106)$ \\
\hline \multirow[t]{2}{*}{$\ln$ Dist $_{\mathrm{ij}}$} & $1.715^{* *}$ & $1.820 * *$ & $1.728 * *$ \\
\hline & $(0.865)$ & $(0.867)$ & $(0.864)$ \\
\hline \multirow[t]{2}{*}{ Contig $_{i j}$} & $9.561 * * *$ & $7.076^{* * * *}$ & $9.602^{* * * *}$ \\
\hline & $(1.274)$ & $(1.725)$ & $(1.272)$ \\
\hline \multirow[t]{2}{*}{ Comlang_off $\mathrm{ij}_{\mathrm{ij}}$} & 2.799 ** & 0.186 & $2.750^{* * *}$ \\
\hline & $(1.092)$ & $(1.167)$ & $(1.075)$ \\
\hline \multirow[t]{2}{*}{ Comcol $_{i j}$} & $7.530^{* * * *}$ & $5.148 * *$ & $7.604 * * * *$ \\
\hline & $(2.278)$ & $(2.268)$ & $(2.274)$ \\
\hline \multirow[t]{2}{*}{$\mathrm{FDI}_{\text {it }}$} & $-0.000000969^{*}$ & $-0.000000151^{* * * *}$ & 0.0000846 \\
\hline & $(0.000000503)$ & $(0.0000000525)$ & $(0.00196)$ \\
\hline \multirow[t]{2}{*}{$\mathrm{FDI}_{\mathrm{jt}}$} & -0.0000000521 & $-0.000000234 * * *$ & $-0.0183^{*}$ \\
\hline & $(0.00000134)$ & $(0.0000000771)$ & $(0.00943)$ \\
\hline \multirow[t]{2}{*}{ RTA $_{i j t}$} & $0.702 * * *$ & $0.400 * *$ & $0.774 * * *$ \\
\hline & $(0.158)$ & $(0.156)$ & $(0.141)$ \\
\hline \multirow[t]{2}{*}{ Constant } & $-11.62^{*}$ & $-12.78^{*}$ & $-11.68^{*}$ \\
\hline & $(6.990)$ & $(7.008)$ & $(6.982)$ \\
\hline Observations & 5,260 & 5,260 & 5,260 \\
\hline R-squared & 0.807 & 0.868 & 0.809 \\
\hline Country FE & YES & YES & YES \\
\hline Year FE & YES & YES & YES \\
\hline
\end{tabular}

From Table 2, assessing the aspect of FDI growth, it can be ascertained that importers' FDI growth negatively influences bilateral trade in Nigeria. Both the Nigerian and full samples reported the same outcome and were statistically significant. On the other hand, the exporters' FDI growth seems to also have a negative co-efficient but was not statistically significant. 
The argument here is that importers' FDI growth negatively affects bilateral trade flow. Trade here was represented as import which makes all trading countries an importer and also is why the exporters' and importers' effects were similar. Therefore, one can say that the importers' FDI growth could limit importation because with the increase in FDI, the importers will have more inputs to manufacture and supply the products that were previously imported. This will make the country more self-reliant than dependent on trade to satisfy its domestic demand. Foreign direct investment in Nigeria seems to be for the sole purpose of satisfying its domestic needs. As the largest country in Africa with approximately 200 million residents, the Nigerian market is very large and therefore needs more products to augment its current demand. Most of the foreign investment in recent years have been for this purpose which was why the result has indicated that the importers' FDI has a negative and significant impact on the nation's bilateral trade.

Hence, in order for Nigeria, to reduce the amount of imports, it should be able to encourage more FDI which will generate more goods for exportation and hinder more importation so as to balance trade. It should be noted that the country is more or less a mono-export dependent country due to its over reliance on crude oil to balance its trade deficit. One would like to suggest that the country creates an enabling business environment to further attract more foreign investment with advanced technologies that will aid export diversification.

\subsection{Trade, RTA and Gravity Variables}

Nigeria is one of the founding members of ECOWAS. The sole purpose of its formation was to allow for the free movement of goods and other factors of production within the region. Estimating the impact of regional trade agreement in this model, it was established that RTA has a positive and significant influence on bilateral trade with Nigeria. The estimation reveals that RTA contributes to over a 101.78 per cent increase in Nigeria's trade, all things being equal and depending on the model being estimated. Though there are challenges, the purpose for which Nigeria became ECOWAS member has been realised given its contribution to the development of Nigeria's trade. Regional trade agreement was measured as having a bilateral impact.

Gravity variables as used in this research included importers' and exporters' GDP, distance, contiguity, common official language, and common colony. Both the exporter and importer GDP were consistent with trade literature as positive and significant which was supported by estimation with Nigerian and full samples. This indicated that both variables influence trade positively and significantly in Nigeria.

Distance seems to have a positive influence on Nigeria's bilateral trade which is an exception from the trade literature. However, the full sample was consistent with the literature as it had negative and significant coefficients. One reason could be that Nigeria's major trading partners, both traditional and emerging ones, are located further away while closer countries trade less with Nigeria, comparatively. This is because the raw materials exported from Nigeria have been demanded by these advanced and emerging economies.

Based on the estimation results, contiguity, common official language and common colonisation history have a positive and significant impact on Nigeria's bilateral trade. Therefore, neighbouring countries trade more with Nigeria that it ought to have otherwise. Likewise, countries that speak the same official language as Nigeria tend to trade more with Nigeria. Also, the countries with a common colonisation history with Nigeria also trade more with Nigeria than if they didn't share the same colonisation history. Except for distance, all other gravity model related variables were consistent with trade literature.

\section{CONCLUSIONS}

The aim of this paper was to investigate the input of foreign direct investment towards the development of bilateral trade in Nigeria. Though the literature has diverse opinions on how FDI influences bilateral trade, it should be noted that the motives of FDI determine the extent of its influence on bilateral trade development. In this research, the gravity model was augmented to accommodate the variables in contention and some interesting 
revelation are paramount. With the PPML technique, we controlled for multilateral resistances and unobserved endogeneity by applying relevant fixed effects.

The research revealed that foreign direct investment may be impacting negatively on bilateral trade flow in Nigeria especially if the estimation is based on FDI stock. While that could also be true with exporters' FDI flow, the influence of the importers' FDI inflow was not statistically significant. Therefore, one can say that the importers' FDI stock could limit importation, because with the availability of FDI, the importer will have more inputs to manufacture and meet domestic demand. Hence Nigeria, to reduce the amount of imports, should encourage more FDI which will generate more goods for exportation and hinder more importation so as to balance trade. Diversifying exports in the country is achievable if FDI with high technology is attracted.

Funding: This study received no specific financial support.

Competing Interests: The authors declare that they have no competing interests.

Acknowledgement: All authors contributed equally to the conception and design of the study.

\section{REFFERENCES}

Adelegan, J. O. (2000). Foreign direct investment and economic growth in Nigeria: A seemingly unrelated model. African Revierw of Money Finance and Banking, Supplementary Issue of Saving and Development, 2000, 5-25.

Adeniyi, O. A., Omisakin, D., Olusegun, A., Egwaikhide, F., \& Oyinlola, A. (2012). Foreign direct investment, economic growth and financial sector development in small open developing economies. Economic Analysis \& Policy, 42(1), 105-127. Available at: https://doi.org/10.1016/s0313-5926(12)50008-1.

Agmon, T. (1979). Direct investment and intra-industry trade: Substitutes or complements? In H.Giersch (Ed.), On the Economics of Intra-Industry Trade: Symposium 1978 (pp. 49-62). Germany, Tübingen: J.C.B. Mohr.

Aizenman, J., \& Noy, I. (2006). FDI and trade—two-way linkages? The Quarterly Review of Economics and Finance, 46(3), $317-337$.

Akinlo, A. E. (2004). Foreign direct investment and growth in Nigeria: An empirical investigation. Journal of Policy Modeling, 26(5), 627-639.

Alfaro, L., Chanda, A., Kalemli-Ozcan, S., \& Sayek, S. (2010). Does foreign direct investment promote growth? Exploring the role of financial markets on linkages. Journal of Development Economics, 91(2), 242-256. Available at: https://doi.org/10.1016/j.jdeveco.2009.09.004.

Aliyu, S. U. R., \& Bawa, S. (2015). Gravity model by panel data approach: Empirical evidence from Nigeria. International Journal of Trade and Global Markets, 8(1), 42-57. Available at: https://doi.org/10.1504/ijtgm.2015.067972.

Anderson, J. E., \& Wincoop, V. E. (2003). Gravity with gravitas: A solution to the border puzzle. American Economic Revierw, 93(1), 170-192. Available at: https://doi.org/10.1257/000282803321455214.

Anderson., J. E. (1979). A theoretical foundation for the gravity equation. The American Economic Revierw, 69(1), 106-1 16.

Azu, N. P. (2019). Trade realignment position in ECOWAS with gravity model. International Journal of Economic Policy in Emerging Economies, 12(2), 103-112. Available at: https://doi.org/10.1504/ijepee.2019.099711.

Baier, S. L., \& Bergstrand, J. H. (2007). Do free trade agreements actually increase members' international trade? Journal of International Economics, 71(1), 72-95. Available at: https://doi.org/10.1016/j.jinteco.2006.02.005

Burange, L., Thakur, P., \& Kelkar, H. K. (2017). Foreign direct investment and intra-industry trade in India's manufacturing sector: A causal relationship. Foreign Trade Review, 52(4), 203-218. Available at: https://doi.org/10.1177/0015732516660797.

Chakraborty, C., \& Basu, P. (2002). Foreign direct investment and growth in India: A cointegration approach. Applied Economics, 34(9), 1061-1073. Available at: https://doi.org/10.1080/000368401 10074079.

Chen, H., \& Swenson, D. (2014). Multinational exposure and the quality of new Chinese exports. Oxford Bulletin of Economics and Statistics, 76(1), 41-66. Available at: https://doi.org/10.1111/j.1468-0084.2012.00726.x.

Dhakal, D., Rahman, S., \& Upadhyaya, K. P. (2007). Foreign direct investment and economic growth in Asia. Indian Journal of Economics and Business, 6(1), 15-26. 
Disdier, A.-C., \& Head, K. (2008). The puzzling persistence of the distance effect on bilateral trade. The Review of Economics and statistics, 90(1), 37-48. Available at: https://doi.org/10.1162/rest.90.1.37.

Egger, P. (2001). European exports and outward foreign direct investment: A dynamic panel data approach. Review of World Economics, 137(3), 427-449. Available at: https://doi.org/10.1007/bfo2707625.

Ehigiamusoe, K. U., \& Lean, H. H. (2019). Foreign capital inflows and economic growth in Nigeria: Any nexus? Journal of African Business, 20(4), 455-471. Available at: https://doi.org/10.1080/15228916.2019.1581010.

Fontagné, L., \& Michaël, P. (1997). How foreign direct investment affects international trade and competitiveness: An empirical assessment. CEPII Working Document Center d'Etudes Prospectives et d'Information Internationales.

Ghatak, A., \& Halicioglu, F. (2007). Foreign direct investment and economic growth: Some evidence from across the world. Global Business and Economics Review, 9(4), 381-394. Available at: https://doi.org/10.1504/gber.2007.015101.

Goldberg, L. S., \& Klein, M. (1998). Foreign direct investment, trade, and real exchange rate linkages in developing countries. In R. Glick (Ed.), Managing Capital Flows and Exchange Rates: Perspectives from the Pacific Basin (pp. 73-100). Cambridge, UK: Cambridge University Press.

Harding, T., \& Javorcik, B. S. (2012). Foreign direct investment and export upgrading. Review of Economics and Statistics, 94(4), 964-980. Available at: https://doi.org/10.1162/rest_a_00226.

Hausmann, R., Hwang, J., \& Rodrik, D. (2007). What you export matters. Journal of Economic Growth, 12(1), 1-25. Available at: https://doi.org/10.1007/s10887-006-9009-4.

Head, K., \& Mayer, T. (2014). Gravity equations: Workhorse, toolkit, and cookbook. In Gopinath, G., Helpman, E., and Rogoff, K. (Eds.), Handbook of International Economics (Vol. 4). Oxford: Elsevier B. V.

Heckman, J. J. (1979). Sample selection bias as a specification error. Econometrica, 47(1), 153-161. Available at: https://doi.org/10.2307/1912352.

Helpman, E. (1984). A simple theory of international trade with multinational corporations. Journal of Political Economy, 92(3), 45 1-471. Available at: https://doi.org/10.1086/261236.

Helpman, E., Melitz, M., \& Rubinstein, Y. (2008). Estimating trade flows: Trading partners and trading volumes. The Quarterly Journal of Economics, 123(2), 441-487. Available at: https://doi.org/10.1 162/qjec.2008.123.2.441.

James, E. A., \& Wincoop, V. E. (2004). Trade costs. Journal of Economic Literature, 42(3), 691-751.

Jawaid, S. T., Raza, S. A., Mustafa, K., \& Karim, M. Z. A. (2016). Does inward foreign direct investment lead export performance in Pakistan? Global Business Review, 17(6), 1296-1313. Available at: https://doi.org/10.1 177/0972150916660394.

Jayachandran, G., \& Seilan, A. (2010). A causal relationship between trade, foreign direct investment and economic growth for India. International Research Journal of Finance and Economics, 42, 74-88.

Le, T. H. (2017). Does economic distance affect the flows of trade and foreign direct investment? Evidence from Vietnam. Cogent Economics \& Finance, 5(1), 1403108. Available at: https://doi.org/10.1080/23322039.2017.1403108.

Lensink, R., \& Morrissey, O. (2006). Foreign direct investment: Flows, volatility, and the impact on growth. Review of International Economics, 14(3), 478-493. Available at: https://doi.org/10.1111/j.1467-9396.2006.00632.x.

Markusen, J. R. (1984). Multinationals, multi-plant economies, and the gains from trade. Journal of International Economics, 16(34), 205-226. Available at: https://doi.org/10.1016/s0022-1996(84)8000 1-x.

Markusen., J. R., \& Venables, A. J. (1995). Multinational firms and the new trade theory. NBER Working Paper, No. 5036. NBER, Cambridge.

Markusen.., J. R. (1997). Trade versus investment liberalization. NBER Working Paper, No. 6231, NBER, Cambridge.

Markusen.., J. R., \& Maskus, K. E. (1999). Discriminating among alternative theories of the multinational enterprise. NBER Working Paper, No. 7164, NBER, Cambridge.

Martin, W., \& Pham, C. S. (2008). Estimating the gravity model when zero trade flows are frequent. Paper presented at the ACE 2008: Abstracts from the 37th Australian Conference of Economists. The Economic Society of Australia. 
Mohamed, S. (2014). Does foreign direct investment increase exports' productivity? Evidence from developing and emerging countries. International Review of Applied Economics, 28(4), 482-506. Available at: https://doi.org/10.1080/02692171.2014.896879.

Mohanty, S., \& Sethi, N. (2019). Does inward FDI lead to export performance in India? An empirical investigation. Global Business Review, 1-16. Available at: https://doi.org/10.1177/0972150919832770.

Muhammad, S. D., Azu, N. P., \& Oko, N. F. (2018). Influence of real exchange rate and volatility on FDI inflow in Nigeria. International Business Research, 11(6), 73-82. Available at: https://doi.org/10.5539/ibr.v1 1n6p73.

Rodrik, D. (2006). What's so special about China's exports? China \& World Economy, 14(5), 1-19. Available at: https://doi.org/10.1111/j.1749-124x.2006.00038.x.

Sahoo, K., \& Sethi, N. (2017). Impact of foreign capital on economic development in India: An econometric investigation. Global Business Review, 18(3), 766-780. Available at: https://doi.org/10.1177/0972150917692198.

Santos, S. J. M. C., \& Tenreyro, S. (2006). The log of gravity. The Review of Economic and Statistics, 88(4), 641-658. Available at: https://doi.org/10.1162/rest.88.4.641.

Shepherd, B. (2013). Gravity model of international trade: A user guide. New Dehli: United Nations Economic and Social Commission for Asia Pacific.

Silva, J. S., \& Tenreyro, S. (2011). Further simulation evidence on the performance of the poisson pseudo-maximum likelihood estimator. Economics Letters, 112(2), 220-222. Available at: https://doi.org/10.1016/j.econlet.201 1.05.008.

Temiz, D., Gökmen, A., \& Abubakar, M. S. (2015). Foreign direct investment and its impact on economic performance: The case of Turkey and Nigeria. Journal of Transnational Management, 20(4), 207-230. Available at: https://doi.org/10.1080/15475778.2015.1095572.

Wang, Z., \& Wei, S. J. (2010a). What accounts for the rising sophistication of China's exports? In China's Growing Role in World Trade, edited by R. Feenstra and S. J. Wei (pp. 35-63). Chicago, IL: University of Chicago Press.

Wang, Z., \& Wei, S. J. (2010b). The Chinese export bundles: Patterns, puzzles, and possible explanations. In Emerging Giants: China and India in the World Economy, edited by B. Eichengreen, P. Gupta, and R. Kumar (pp. 62-81). New York: Oxford University Press.

Xiong, B., \& Chen, S. (2012). Estimating gravity equation models in the presence of sample selection and heteroskedasticity. Paper presented at the In Agriculture and Applied Economics Association's Annual Meeting, Seattle.

Yusoff, M. B., \& Nuh, R. (2015). Foreign direct investment, trade openness and economic growth: Empirical evidence from Thailand. Foreign Trade Review, 50(2), 73-84. Available at: https://doi.org/10.1177/0015732515572055.

Zhang, Q., \& Felmingham, B. (2001). The relationship between inward direct foreign investment and China's provincial export trade. China Economic Review, 12(1), 82-99. Available at: https://doi.org/10.1016/s1043-951x(01)00044-x.

\section{APPENDIX}

Appendix-1. Summary Statistics.

\begin{tabular}{c|c|c|c|c|c}
\hline Variable & Obs & Mean & Std. Dev. & Min & Max \\
\hline $\mathrm{M}_{\mathrm{ijt}}$ & 212,111 & 1114.579 & 7530.499 & 0 & 481880.8 \\
\hline $\ln \mathrm{Y}_{\mathrm{it}}$ & 217,922 & -0.54204 & 2.301774 & -6.50104 & 5.188796 \\
\hline $\ln \mathrm{Y}_{\mathrm{jt}}$ & 217,922 & -0.5442 & 2.303428 & -6.50104 & 5.188796 \\
\hline $\ln \mathrm{Dist}_{\mathrm{ij}}$ & 214,165 & 8.610077 & 0.796314 & 4.741773 & 9.881444 \\
\hline Contig $_{\mathrm{ij}}$ & 219,660 & 0.028043 & 0.165097 & $\mathrm{O}$ & 1 \\
\hline Comlang_off $_{\mathrm{ij}}$ & 219,660 & 0.140854 & 0.347872 & 0 & 1 \\
\hline Comcol $_{\mathrm{ij}}$ & 219,660 & 0.078075 & 0.268291 & 0 & 1 \\
\hline FDI $_{\mathrm{it}}$ & 212,918 & 8388.767 & 24337.46 & -31689.3 & 379894 \\
\hline FDI $_{\mathrm{jt}}$ & 212,977 & 8386.071 & 24334.85 & -31689.3 & 379894 \\
\hline RTA $_{\mathrm{ijt}}$ & 219,660 & 0.164582 & 0.370803 & 0 & 1 \\
\hline
\end{tabular}


Appendix-2. Correlation.

\begin{tabular}{|c|c|c|c|c|c|c|c|c|c|c|}
\hline Variables & $\mathbf{M}_{\mathrm{ijt}}$ & $\ln \mathrm{Y}_{\text {it }}$ & $\ln \mathrm{Y}_{\mathrm{jt}}$ & $\operatorname{lnDist}_{\mathrm{ij}}$ & Contig $_{i j}$ & C-L off ${ }_{i j}$ & Comcol $_{\mathrm{ij}}$ & FDI $_{\text {it }}$ & FDI $_{\text {jt }}$ & $\mathbf{R T A}_{\mathrm{ijt}}$ \\
\hline $\mathrm{M}_{\mathrm{ijt}}$ & 1 & & & & & & & & & \\
\hline $\ln \mathrm{Y}_{\mathrm{it}}$ & 0.198 & 1 & & & & & & & & \\
\hline $\ln \mathrm{Y}_{\mathrm{jt}}$ & 0.1983 & 0.0465 & 1 & & & & & & & \\
\hline ln Dist $\mathrm{Dij}_{\mathrm{ij}}$ & -0.1154 & 0.0987 & 0.0962 & 1 & & & & & & \\
\hline Contig $_{i j}$ & 0.1986 & -0.0111 & -0.0103 & -0.4023 & 1 & & & & & \\
\hline C-L off $i j$ & 0.0356 & -0.0926 & -0.0919 & -0.1454 & 0.1571 & 1 & & & & \\
\hline Comcol $_{i j}$ & -0.0356 & -0.1855 & -0.1844 & -0.1529 & 0.1326 & 0.38 & 1 & & & \\
\hline $\mathrm{FDI}_{\text {it }}$ & 0.2241 & 0.4529 & 0.0572 & 0.0534 & 0.0048 & 0.023 & -0.0696 & 1 & & \\
\hline $\mathrm{FDI}_{j \mathrm{t}}$ & 0.2657 & 0.0559 & 0.4527 & 0.0534 & 0.0048 & 0.023 & -0.0697 & 0.0621 & 1 & \\
\hline $\mathrm{RTA}_{\mathrm{ijt}}$ & 0.1148 & 0.1317 & 0.068 & -0.4862 & O.1689 & 0.0289 & -0.0236 & 0.048 & 0.0214 & 1 \\
\hline
\end{tabular}

Appendix-3. Effect of FDI on bilateral trade (FULL SAMPLE).

\begin{tabular}{|c|c|c|c|}
\hline & $(1)$ & $(2)$ & (3) \\
\hline Variables & Flow & Stock & Growth \\
\hline \multirow[t]{2}{*}{$\ln \mathrm{Y}_{\mathrm{it}}$} & $0.693^{* * *}$ & $0.670^{* * *}$ & $0.675^{* * *}$ \\
\hline & $(0.0210)$ & $(0.0220)$ & $(0.0211)$ \\
\hline \multirow[t]{2}{*}{$\ln \mathrm{Y}_{\mathrm{jt}}$} & $0.759^{* * *}$ & $0.745^{* * *}$ & $0.753^{* * *}$ \\
\hline & $(0.0205)$ & $(0.0204)$ & $(0.0203)$ \\
\hline \multirow[t]{2}{*}{$\ln$ Dist $_{\mathrm{ij}}$} & $-0.751^{* * *}$ & $-0.750^{* * *}$ & $-0.752^{* * *}$ \\
\hline & $(0.00812)$ & $(0.00813)$ & $(0.00815)$ \\
\hline \multirow[t]{2}{*}{ Contig $_{i j}$} & $0.384^{* * * *}$ & $0.384^{* * * *}$ & $0.384^{* * * *}$ \\
\hline & $(0.0168)$ & $(0.0168)$ & $(0.0168)$ \\
\hline \multirow[t]{2}{*}{ Comlang_off ${ }_{\mathrm{ij}}$} & $0.149 * * *$ & $0.147 * * *$ & $0.150^{* * * *}$ \\
\hline & $(0.0162)$ & $(0.0162)$ & $(0.0162)$ \\
\hline \multirow[t]{2}{*}{ Comcol $_{i j}$} & $0.146^{* * *}$ & $0.147^{* * * *}$ & $0.146^{* * * *}$ \\
\hline & $(0.0441)$ & $(0.0443)$ & $(0.0440)$ \\
\hline \multirow[t]{2}{*}{$\mathrm{FDI}_{\text {it }}$} & $-0.000000708^{*} * *$ & $-0.0000000931^{* * * *}$ & 0.0000493 \\
\hline & $(0.000000131)$ & $(0.0000000103)$ & $(0.000854)$ \\
\hline \multirow[t]{2}{*}{$\mathrm{FDI}_{\mathrm{jt}}$} & -0.000000261 & $-0.00000000413^{* * *}$ & -0.000732 \\
\hline & $(0.000000165)$ & $(0.0000000132)$ & $(0.000754)$ \\
\hline \multirow[t]{2}{*}{$\mathrm{RTA}_{\mathrm{ijt}}$} & $0.303 * * *$ & $0.308^{*} * *$ & $0.299 * * *$ \\
\hline & $(0.0154)$ & $(0.0153)$ & $(0.0156)$ \\
\hline \multirow[t]{2}{*}{ Constant } & $10.86^{* * *}$ & $10.76^{* * * *}$ & $10.88^{* * * *}$ \\
\hline & $(0.102)$ & $(0.104)$ & $(0.102)$ \\
\hline Observations & 219,660 & 219,660 & 219,660 \\
\hline R-squared & 0.891 & 0.890 & 0.891 \\
\hline Country FE & YES & YES & YES \\
\hline Year FE & YES & YES & YES \\
\hline
\end{tabular}

Note: Robust standard errors in parentheses. Analysis is done with PPML technique.

*** $\mathrm{p}<0.01, * *$ $\mathrm{p}<0.05, * \mathrm{p}<0.1$. 